\title{
Anti-gout potential of selected edible flowers
}

\author{
Rosli, N.-F., *Abu Bakar, M.F., Abu Bakar, F.I. and Lim, S.Y. \\ Department of Technology and Natural Resources, Faculty of Applied Sciences and Technology, Universiti \\ Tun Hussein Onn Malaysia (UTHM) - Pagoh Campus, Pagoh Higher Education Hub, KM 1, Jalan \\ Panchor, 84600 Muar, Johor, Malaysia
}

\begin{abstract}
Article history:
Received: 3 March 2021

Received in revised form: 17 April 2021

Accepted: 28 June 2021

Available Online: 26 January 2022
\end{abstract}

\section{Keywords:}

Anti-gout,

Flowers,

Xanthine oxidase,

Phenolic,

Flavonoid,

Anthocyanin

\section{DOI:}

https://doi.org/10.26656/fr.2017.6(1).156

\begin{abstract}
Gout is a form of inflammatory arthritis triggered by the interaction between monosodium urate crystals and tissues during the purine metabolism by xanthine oxidase. This study aimed to determine the xanthine oxidase inhibitory activity, total phenolic content, total flavonoid content and total anthocyanin content of 10 selected edible flowers, namely Rosa sp., Malus sp., Lavandula sp., Lilium sp., Hibiscus sabdariffa L., Chrysanthemum sp., Matricaria sp., Gomphrena sp., Myosotis sp. and Jasminum sp. extracted using hot water infusion method. Phytochemical contents and the anti-gout activity of the flower extracts using the xanthine oxidase inhibition assay were determined spectrophotometrically. The results revealed that three aqueous flower extracts (Rosa sp., Hibiscus sabdariffa L. and Malus sp.) exhibited potent xanthine oxidase inhibitory activity ( $\mathrm{IC}_{50}$ values, $0.10 \pm 0.15 \mu \mathrm{g} / \mathrm{mL}, 0.12 \pm 0.11 \mu \mathrm{g} / \mathrm{mL}$ and $2.59 \pm 3.8 \mu \mathrm{g} / \mathrm{mL}$, respectively), which were comparable to the positive control, allopurinol ( $\mathrm{IC}_{50}$ value, $4.9 \pm 0.00 \mu \mathrm{g} / \mathrm{mL}$ ). The highest phenolic and flavonoid contents were found in Lavandula sp. $(4.39 \pm 0.13 \mathrm{mg}$ GAE/g and $63.46 \pm 1.07 \mathrm{mg} \mathrm{RE} / \mathrm{g}$ ) while Rosa sp. showed the highest content of anthocyanin $(70.14 \pm 4.82 \mathrm{mg} \mathrm{c}-3-\mathrm{gE} / \mathrm{g})$. Positive correlations were observed between the phytochemicals and xanthine oxidase inhibitory activity of the flower extracts. Hence, this study suggests that Rosa sp., Hibiscus sabdariffa L. and Malus sp. possess anti-gout potential, which is associated with the presence of possible anti-gout phytochemicals. The isolation of the bioactive compounds that exhibit significant anti-gout activity among the selected flowers is recommended for future research.
\end{abstract}

\section{Introduction}

Gout is a type of arthritis associated with joint pain and swelling which occurs due to the increase of uric acid in the blood. Xanthine oxidase is an enzyme that controls the uric acid level by catalyzing the oxidative hydroxylation of hypoxanthine to xanthine, then to uric acid (Abu Bakar et al., 2018). The inflammation response is initiated with the formation of monosodium urate crystals at the joints and tissues under abnormally high uric acid levels as a consequence of gout development (Abu Bakar et al., 2018). Allopurinol is the most common drug used for gout treatment and acts as a xanthine oxidase inhibitor, but it causes several side effects including acute renal and hepatic failure, gastrointestinal distress, hypersensitivity reactions and skin rash (Chen et al., 2005; Pacher et al., 2006). Hence, searching for novel xanthine oxidase inhibitors with greater therapeutic potential and fewer side effects is highly needed.

There is a vast array of natural products potentially to be developed as xanthine oxidase inhibitors, at present, the research related to this discovery is still largely unexplored (Hudaib et al., 2011). Flower and herbal tea infusions have been gaining popularity among researchers due to their nutritional value and therapeutic importance. In addition, refreshing tea infusions made from the pure or powdered forms of flowers are popular due to their fragrance, antioxidant properties and therapeutic applications (Aoshima et al., 2007). Its taste, aroma and health benefits also contribute to increased attention and interest for flower teas consumption (Hussain et al., 2019).

Phenolics and flavonoids, including anthocyanins, are the most common phytochemicals found in edible flowers (Kumari et al., 2021). Phytochemical screening 
of plant extracts has revealed that these compounds may act as anti-gout agents by inhibiting the biosynthesis of uric acid and it is worthy of further research on other samples (Unno et al., 2004). Thus, this study aimed to evaluate the anti-gout activity and phytochemical contents such as phenolics, flavonoids and anthocyanins among the selected edible flowers.

\section{Materials and methods}

\subsection{Chemicals and reagents}

Gallic acid, rutin, allopurinol and xanthine substrate were purchased from Acros Organics (Fair Lawn, New Jersey, United States). Folin Ciocalteu reagent, aluminium chloride hexahydrate, sodium hydroxide, disodium hydrogen phosphate heptahydrate and potassium chloride were obtained from Merck (Darmstadt, Germany). Sodium carbonate and sodium nitrite were acquired from Fisher Scientific (Hampton, New Hampshire, United States). Xanthine oxidase from bovine milk, hydrochloric acid $(0.5 \mathrm{M})$ and sodium phosphate monobasic was bought from Sigma-Aldrich (St. Louis, Missouri, United States).

\subsection{Flowers selection and identification}

A total of ten dried flowers, namely Rosa sp., Malus sp., Lavandula sp., Lilium sp., Hibiscus sabdariffa L., Chrysanthemum sp., Matricaria sp., Gomphrena sp., Myosotis sp. and Jasminum sp. were purchased in the marketplace at Jonker Walk, Malacca, Malaysia. Two main criteria were established for the sample selection; (1) plant parts used such as a flower in this case, and (2) anti-inflammatory properties of flowers based on the literature. All the flower samples were identified through the guidance of information such as plant morphological description, photographs and illustrations from the botanical databases. Next, the dried flowers were pulverized using a grinder (Panasonic, MX-GM1011H, Japan) and kept in the zip lock bags.

\subsection{Extraction of flower}

Each powdered flower $(1 \mathrm{~g})$ was mixed with $100 \mathrm{~mL}$ of boiling water for 3 mins (Abu Bakar et al., 2006). The solution was then filtered through the tea filter bag and left to cool down. The aqueous flower extract was used for further phytochemical content determination and anti -gout activity.

\subsection{Phytochemical testing}

\subsubsection{Determination of total phenolic content}

Total phenolic content was determined by FolinCiocalteu assay (Mohd Noor et al., 2020) using gallic acid as the standard. An amount of $0.9 \mathrm{~mL}$ of distilled water was mixed with $2 \mathrm{~mL}$ of ten-fold diluted Folin
Ciocalteu reagent and $0.1 \mathrm{~mL}$ of aqueous flower extract. After 5 mins, a $2 \mathrm{~mL}$ of $7 \%(\mathrm{w} / \mathrm{v})$ sodium carbonate solution was added to the mixture and incubated for 30 mins at room temperature. The absorbance values of the reaction mixtures were measured at $760 \mathrm{~nm}$ using T60 UV-Vis spectrophotometer (PG Instruments Limited, United Kingdom) and the results were expressed as $\mathrm{mg}$ gallic acid equivalent (GAE) per gram of flower sample.

\subsubsection{Determination of total flavonoid content}

Total flavonoid content was determined using the aluminium chloride colourimetric method (Ali Hassan and Abu Bakar, 2013) and rutin was used as the standard. An amount of $1 \mathrm{~mL}$ of aqueous flower extract was diluted with $4 \mathrm{~mL}$ of distilled water and then mixed with $0.3 \mathrm{~mL}$ of $5 \%$ sodium nitrite solution and $0.3 \mathrm{~mL}$ of $10 \%$ aluminium chloride hexahydrate. The mixture was kept for 5 mins. About $2 \mathrm{~mL}$ of $1 \mathrm{M}$ sodium hydroxide was added to the mixture and mixed using a vortex mixer (Labmart, LM-3000, Malaysia). The absorbance values of the reaction mixtures were measured at $510 \mathrm{~nm}$ using a T60 UV-Vis spectrophotometer (PG Instruments Limited, United Kingdom). The results were expressed as $\mathrm{mg}$ rutin equivalent $(\mathrm{RE})$ per gram of flower sample.

\subsubsection{Determination of total anthocyanin content}

Total anthocyanin content was determined using spectrophotometric $\mathrm{pH}$ differential protocol with some modification (Giusti and Wrolstad, 2001). A $3.5 \mathrm{~mL}$ of potassium chloride buffer $(0.025 \mathrm{M}$; $\mathrm{pH} 1.0)$ was added into $0.5 \mathrm{~mL}$ of aqueous flower extract. The mixture was mixed using a vortex mixer (Labmart, LM-3000, Malaysia) and allowed to stand for 15 mins. The absorbance values of the reaction mixtures were measured at $515 \mathrm{~nm}$ and $700 \mathrm{~nm}$ against blank as distilled water using a T60 UV-Vis spectrophotometer (PG Instruments Limited, United Kingdom). The results were expressed as mg cyanidin-3glucoside equivalent (c$3-\mathrm{gE})$ per gram of flower sample.

\subsection{Anti-gout activity}

Xanthine oxidase inhibition assay is an enzyme assay used to determine the anti-gout activity of the plant extracts (Abu Bakar et al., 2020) and it was conducted based on the study of Unno et al. (2004) with some modifications. Allopurinol $(100 \mu \mathrm{g} / \mathrm{mL})$ was used as the positive control in this study. The inhibitory effect on xanthine oxidase was measured spectrophotometrically at $295 \mathrm{~nm}$ (Ahmad et al., 2006). The reaction mixture consisted of $0.3 \mathrm{~mL}$ of $50 \mathrm{mM}$ sodium phosphate buffer (pH 7.5), $0.1 \mathrm{~mL}$ of flower extract or standard solution $(10-100 \mu \mathrm{g} / \mathrm{mL})$ dissolved in distilled water, $0.1 \mathrm{~mL}$ of freshly prepared enzyme solution $(0.2$ units $/ \mathrm{mL}$ of XO in phosphate buffer) and $0.1 \mathrm{~mL}$ of distilled water. The 
assay mixture was pre-incubated at $37^{\circ} \mathrm{C}$ for 15 mins. Then, a $0.2 \mathrm{~mL}$ of substrate solution $(0.15 \mathrm{mM}$ of xanthine) was added to the mixture. The reaction mixture was incubated at $37^{\circ} \mathrm{C}$ for 30 mins. Next, the reaction was stopped with the addition of $0.2 \mathrm{~mL}$ of $0.5 \mathrm{M}$ hydrochloric acid. The absorbance values of the reaction mixtures were measured using a UV-VIS spectrophotometer (PG Instruments Limited, United Kingdom) against a blank prepared in the same way but the enzyme solution was replaced with the phosphate buffer. Another reaction mixture was prepared (control) having $0.1 \mathrm{~mL}$ of distilled water instead of test compounds in order to have maximum uric acid formation. The degree of xanthine oxidase inhibitory activity was evaluated according to equation (1) (Nessa et al., 2010):

$$
\text { Inhibition }(\%)=\left(1-\frac{B}{A}\right) \times 100
$$

Where $\mathrm{A}$ is the absorbance of the enzyme without extract and $\mathrm{B}$ is the absorbance of the enzyme with the extract. The half-maximal inhibitory concentration $\left(\mathrm{IC}_{50}\right)$ is defined as the concentration of the test samples required to inhibit $50 \%$ of the xanthine oxidase enzyme, which concomitantly decreases the uric acid production by $50 \%$ (Nessa et al., 2010). IC $_{50}$ values were obtained through the slope of the plot of the percentage inhibition against various concentrations of samples.

\subsection{Statistical analysis}

All experiments were carried out in triplicate. The correlation analysis was done to evaluate the association between the phytochemicals and xanthine oxidase inhibitory activity using the Pearson correlation test.

\section{Results and discussion}

\subsection{Phytochemical contents of the selected flowers}

The total phenolic, flavonoid and anthocyanin contents in the selected flowers were determined in this study (Table 1). Overall, the total phenolic content of flower extracts ranged from $0.45 \pm 0.03$ to $4.39 \pm 0.13 \mathrm{mg}$
GAE/g. The highest phenolic content was observed in Lavandula sp. extract with the value of $4.39 \pm 0.13 \mathrm{mg}$ GAE/g. The second and third highest phenolic contents were recorded in Rosa sp. (3.89 $\pm 0.19 \mathrm{mg} \mathrm{GAE} / \mathrm{g})$ and Malus sp. (3.79 $\pm 0.20 \mathrm{mg} \mathrm{GAE} / \mathrm{g})$, respectively, followed by Chrysanthemum sp. (2.88 $\pm 0.23 \mathrm{mg} \mathrm{GAE} / \mathrm{g})$, Myosotis sp. (1.77 $\pm 0.07 \mathrm{mg}$ GAE/g), Lilium sp. $(1.29 \pm 0.12 \mathrm{mg}$ $\mathrm{GAE} / \mathrm{g})$, Matricaria sp. $(0.89 \pm 0.09 \mathrm{mg}$ GAE/g), Hibiscus sabdariffa L. $(0.89 \pm 0.05 \mathrm{mg}$ GAE $/ \mathrm{g})$, Jasminum sp. $(0.71 \pm 0.04 \mathrm{mg} \mathrm{GAE} / \mathrm{g})$ and Gomphrena sp. $(0.45 \pm 0.03 \mathrm{mg} \mathrm{GAE} / \mathrm{g})$.

Additionally, the range of total flavonoid content of flower extracts was within $2.56 \pm 0.58$ to $63.46 \pm 1.07 \mathrm{mg}$ RE/g. Lavandula sp. also showed the highest flavonoid content with the value of $63.46 \pm 1.07 \mathrm{mg} \mathrm{RE} / \mathrm{g}$. Total flavonoid contents of other flower extracts were shown in the descending order of Chrysanthemum sp. (52.19 $\pm 0.20 \mathrm{mg} \mathrm{RE} / \mathrm{g})$, Malus sp. (28.69 $\pm 0.13 \mathrm{mg} \mathrm{RE} / \mathrm{g}$ ), Myosotis sp. $\quad(15.85 \pm 1.65 \mathrm{mg}$ RE/g), Rosa sp. $(13.13 \pm 0.93 \mathrm{mg} \quad \mathrm{RE} / \mathrm{g})$, Hibiscus sabdariffa $\mathrm{L}$. (11.57 $\pm 0.89 \mathrm{mg} \mathrm{RE} / \mathrm{g})$, Matricaria $\mathrm{sp} .(10.84 \pm 0.27 \mathrm{mg}$ $\mathrm{RE} / \mathrm{g})$, Lilium sp. $(8.87 \pm 1.03 \mathrm{mg} \mathrm{RE} / \mathrm{g})$, Jasminum sp. $(8.68 \pm 1.08 \mathrm{mg} \mathrm{RE} / \mathrm{g})$ and Gomphrena sp. $(2.56 \pm 0.58 \mathrm{mg}$ $\mathrm{RE} / \mathrm{g})$.

The presence of anthocyanin was observed among the flower extracts with the range from $2.23 \pm 2.78$ to $70.14 \pm 4.82 \mathrm{mg} \mathrm{c}-3-\mathrm{gE} / \mathrm{g}$. The high anthocyanin contents were found in Rosa sp. with the value of $70.14 \pm 4.82 \mathrm{mg}$ c-3-gE/g, followed by Myosotis sp. (34.51 $\pm 18.18 \mathrm{mg} \mathrm{c}-3$ -gE/g), Lilium sp. (26.05 $\pm 2.00 \mathrm{mg} \mathrm{c}-3-\mathrm{gE} / \mathrm{g})$, Lavandula sp. $(22.93 \pm 5.1982 \mathrm{mg} \mathrm{c}-3-\mathrm{gE} / \mathrm{g})$, Hibiscus sabdariffa L. (8.91 $\pm 1.39 \mathrm{mg}$ c-3-gE/g), Chrysanthemum sp.

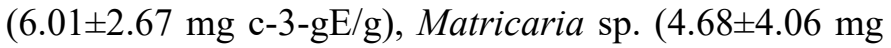
c-3-gE/g), Malus sp. $(4.01 \pm 5.22 \quad \mathrm{mg} \quad \mathrm{c}-3-\mathrm{gE} / \mathrm{g})$, Gomphrena sp. (3.79 $\pm 2.04 \mathrm{mg}$ c-3-gE/g) and Jasminum sp. $(2.23 \pm 2.78 \mathrm{mg} \mathrm{c}-3-\mathrm{gE} / \mathrm{g})$.

Phenolic, flavonoid and anthocyanin are the phytochemicals that are naturally found in plants and are

Table 1. Quantitative phytochemical analysis of different flower extracts.

\begin{tabular}{cccc}
\hline Plant extracts & TPC $(\mathrm{mg} \mathrm{GAE} / \mathrm{g})$ & TFC $(\mathrm{mg} \mathrm{RE} / \mathrm{g})$ & TAC $(\mathrm{mg} \mathrm{c}-3-\mathrm{gE} / \mathrm{g})$ \\
\hline Malus sp. & $3.79 \pm 0.20$ & $28.69 \pm 0.13$ & $4.01 \pm 5.22$ \\
Chrysanthemum sp. & $2.88 \pm 0.23$ & $52.19 \pm 0.20$ & $6.01 \pm 2.67$ \\
Matricaria sp. & $0.89 \pm 0.09$ & $10.84 \pm 0.27$ & $4.68 \pm 4.06$ \\
Lavandula sp. & $4.39 \pm 0.13$ & $63.46 \pm 1.07$ & $22.93 \pm 5.19$ \\
Rosa sp. & $3.89 \pm 0.19$ & $13.13 \pm 0.93$ & $70.14 \pm 4.82$ \\
Hibiscus sabdariffa L. & $0.89 \pm 0.05$ & $11.57 \pm 0.89$ & $8.91 \pm 1.39$ \\
Myosotis sp. & $1.77 \pm 0.07$ & $15.85 \pm 1.65$ & $34.51 \pm 18.18$ \\
Gomphrena sp. & $0.45 \pm 0.03$ & $2.56 \pm 0.58$ & $3.79 \pm 2.04$ \\
Jasminum sp. & $0.71 \pm 0.04$ & $8.68 \pm 1.08$ & $2.23 \pm 2.78$ \\
Lilium sp. & $1.29 \pm 0.12$ & $8.87 \pm 1.03$ & $26.05 \pm 2.00$ \\
\hline
\end{tabular}

Values are presented as mean \pm standard deviation, $\mathrm{n}=3$. TPC: total phenolic content, TFC: total flavonoid content, TAC: total anthocyanin content. 
also known to possess antioxidant, anti-inflammatory, anti-cancer and other pharmacological activities (Tungmunnithum et al., 2018). As shown in the result of the current study, the presence of phenolics, flavonoids and anthocyanins was detected in all the flower extracts. Phenolic compounds including phenolic acid and polyphenols are a major class of secondary metabolites existing in most plants and have proven their ability able to delay the ageing process as well as reduce the health risk (Minatel et al., 2017). Among 10 selected flower extracts, their total phenolic content (0.45-4.39 mg GAE/ g) was found to be much lower than the result shown (8.23-284.8 $\mathrm{mg} \mathrm{GAE} / \mathrm{g}$ ) in the study of Zheng et al. (2018). The result of the top 3 samples (Lavandula sp., Rosa sp. and Malus sp.) with the highest phenolic content in this study was lower as compared to the extracts $(50.8,39.47-284.8,8.23-60.58 \mathrm{mg}$ GAE/g, respectively) studied by Zheng et al. (2018). Besides, the overall phenolic content in the current study was lesser than the study of Jin et al. (2016), which ranged from 1.26 to $24.55 \mathrm{~g} \mathrm{GAE} / 100 \mathrm{~g} \mathrm{dw}$, but the present result of Lavandula sp. (4.39 $\mathrm{mg} \mathrm{GAE} / \mathrm{g}$ ) is comparable to the content of L. angustifolia Mill. (3.50 g GAE/100 g dw) and Rosa spp. were also reported to have a high content of phenolics in the study of Jin et al. (2016).

Flavonoids are an important class of secondary metabolites consisting of a large group of polyphenolic compounds and exhibit various health-promoting effects (Kumar and Pandey, 2013). In total, 10 selected flower extracts were found to have rich flavonoid content (2.56$63.46 \mathrm{mg} \mathrm{RE} / \mathrm{g}$ ) and this was higher than the overall content observed (1.18-25.39 $\mathrm{mg} \mathrm{CAE} / \mathrm{g}$ ) among the similar samples in the previous study (Zheng et al., 2018). Most of the flower extracts possessed higher flavonoid content as compared to the study of Zheng et al. (2018), except the Myosotis sp. extract. The difference between sample origins, the influence of environmental conditions and extraction methods could lead to the variation in the phytochemical composition of phenolics and flavonoids (Abu Bakar et al., 2016; Md Akhir et al., 2017).

Anthocyanins are a subclass of flavonoids that are responsible for pigmentation in plants and fruits and have been widely studied for various medicinal purposes (Khoo et al., 2017). Most red, blue and purple coloured flowers contain anthocyanins and this could relate to the high content of anthocyanins (2.23-70.14 mg c-3-gE/g) observed among the selected flowers, especially Rosa sp., Myosotis sp. and Lilium sp. extracts with their stronger colouration. The comparison between current and previous studies showed that the anthocyanin content of Rosa sp. (70.14 mg c-3-gE/g) was found to be slightly higher than the anthocyanin content of Rosa indica (64.52 mg c-3-gE/g) (Vankar and Srivastava, 2010). The environmental factors such as temperature and light as well as the presence of complex compounds including phenols and other constituents could affect the anthocyanin content present in every plant species, resulting in a variety of flower colours (Bolling et al., 2010; Mohd Noor et al., 2020).

\subsection{Xanthine oxidase inhibitory activity of the selected flowers}

Table 2 displays the inhibition percentages of the standard, allopurinol as well as the flower extracts and their $\mathrm{IC}_{50}$ values. As a result, all flower extracts showed potent xanthine oxidase inhibitory activity, but the inhibition percentages of flower extracts were not in a concentration-dependent manner. The trend is also observed in the study of Wahyuningsih et al. (2016) and this could be due to the increasing metabolites along with the sample concentrations that disturb the inhibition of the xanthine oxidase enzyme. In the present study, Rosa sp. exhibited the strongest xanthine oxidase inhibitory activity with the $\mathrm{IC}_{50}$ value of $0.10 \mu \mathrm{g} / \mathrm{mL}$, as compared to the other 9 flower extracts including Hibiscus sabdariffa L. (0.12 $\mu \mathrm{g} / \mathrm{mL})$, Malus sp. $(2.59 \mu \mathrm{g} /$ $\mathrm{mL})$, Matricaria sp. $(20.89 \mu \mathrm{g} / \mathrm{mL})$, Chrysanthemum sp. (29.04 $\mu \mathrm{g} / \mathrm{mL})$, Lavandula sp. (33.33 $\mu \mathrm{g} / \mathrm{mL})$, Myosotis sp. (59.81 $\mu \mathrm{g} / \mathrm{mL})$, Gomphrena sp. $(65.29 \mu \mathrm{g} / \mathrm{mL})$, Lilium sp. $(77.27 \mu \mathrm{g} / \mathrm{mL})$ and Jasminum sp. $(85.39 \mu \mathrm{g} /$ $\mathrm{mL}$ ). Above all, 3 aqueous flower extracts (Rosa sp., $H$. sabdariffa L. and Malus sp.) displayed stronger xanthine oxidase inhibition ability than the positive control, allopurinol with the $\mathrm{IC}_{50}$ value of $4.9 \mu \mathrm{g} / \mathrm{mL}$.

Xanthine oxidase inhibitors are proven to be effectively used for the treatment of hepatic disease and gout, which is caused by the increased uric acid level and the generation of excessive amounts of superoxide anion radical (Lin et al., 2000). Rosa sp. could be developed as a xanthine oxidase inhibitor because it showed the most significant xanthine oxidase inhibitory activity with the lowest $\mathrm{IC}_{50}$ value in this study. Previous studies stated that rosehip, the fruit of rose plants within the genus Rosa, in particular, Rosa canina L. exhibited potent biological activity including the anti-inflammatory effect (Jäger et al., 2007; Orhan et al., 2007). As reported in the literature, the presence of flavonoid and phenolic compounds (catechin and syringic acid), as well as anthocyanins (cyanidin and pelargonidin), was identified in the Rosa sp. extracts and these compounds have shown their capabilities to inhibit xanthine oxidase (Kovatcheva-Apostolova et al., 2008; Yang and Shin, 2017; Abu Bakar et al., 2018; Malik et al., 2019).

The xanthine oxidase inhibitory potency of other flower extracts could be taken into consideration for the 
Table 2. Percentage of xanthine oxidase inhibition of different flower extracts and the standard, allopurinol.

\begin{tabular}{lcccccc}
\hline \multirow{2}{*}{ Samples } & \multicolumn{5}{c}{ Xanthine Oxidase Inhibition $(\%)$} & \multirow{2}{*}{$\mathrm{IC}_{50}(\mu \mathrm{g} / \mathrm{mL})$} \\
\cline { 2 - 6 } & $10 \mu \mathrm{g} / \mathrm{mL}$ & $25 \mu \mathrm{g} / \mathrm{mL}$ & $50 \mu \mathrm{g} / \mathrm{mL}$ & $75 \mu \mathrm{g} / \mathrm{mL}$ & $100 \mu \mathrm{g} / \mathrm{mL}$ & \\
\hline Lavandula sp. & $47.11 \pm 5.88$ & $35.41 \pm 6.45$ & $22.67 \pm 4.51$ & $74.02 \pm 1.94$ & $83.02 \pm 3.73$ & $33.33 \pm 8.07$ \\
Malus sp. & $75.41 \pm 17.36$ & $69.33 \pm 26.78$ & $50.67 \pm 25.54$ & $80.59 \pm 15.25$ & $96.26 \pm 1.90$ & $2.59 \pm 3.8$ \\
Jasminum sp. & $51.11 \pm 22.07$ & $23.56 \pm 26.34$ & $42.96 \pm 39.23$ & $50.72 \pm 3.73$ & $61.86 \pm 1.67$ & $85.39 \pm 93.06$ \\
Matricaria sp. & $7.41 \pm 5.15$ & $88.59 \pm 10.96$ & $73.04 \pm 11.30$ & $93.94 \pm 3.65$ & $93.54 \pm 3.12$ & $20.8 \pm 2.77$ \\
Rosa sp. & $89.04 \pm 1.35$ & $66.37 \pm 11.89$ & $84.00 \pm 18.97$ & $95.14 \pm 2.78$ & $93.30 \pm 4.00$ & $0.10 \pm 0.15$ \\
Chrysanthemum sp. & $21.19 \pm 11.93$ & $38.22 \pm 27.84$ & $75.85 \pm 15.71$ & $73.35 \pm 28.81$ & $89.24 \pm 5.15$ & $29.04 \pm 5.00$ \\
Myosotis sp. & $37.48 \pm 26.91$ & $52.30 \pm 22.19$ & $62.52 \pm 21.51$ & $56.63 \pm 3.96$ & $59.81 \pm 4.57$ & $57.34 \pm 40.32$ \\
Gomphrena sp. & $10.81 \pm 9.80$ & $14.67 \pm 6.16$ & $11.11 \pm 13.56$ & $64.18 \pm 4.44$ & $77.27 \pm 2.30$ & $65.84 \pm 4.84$ \\
Lilium sp. & $70.37 \pm 42.85$ & $75.56 \pm 3.56$ & $13.93 \pm 24.12$ & $59.52 \pm 8.34$ & $65.96 \pm 3.36$ & $78.37 \pm 13.99$ \\
Hibiscus sabdariffa L. & $79.41 \pm 7.08$ & $78.96 \pm 11.70$ & $74.08 \pm 7.50$ & $92.39 \pm 0.87$ & $91.41 \pm 10.09$ & $0.12 \pm 0.11$ \\
Allopurinol & $61.78 \pm 0.00$ & $75.11 \pm 0.00$ & $82.67 \pm 0.00$ & $92.24 \pm 0.00$ & $98.11 \pm 0.00$ & $4.9 \pm 0.00$ \\
\hline
\end{tabular}

Values are presented as mean \pm standard deviation, $\mathrm{n}=3$.

gout treatment. In the present study, the aqueous extract of Chrysanthemum sp. displayed higher xanthine oxidase inhibitory activity than the result reported by Kong et al. (2000), whereas Bustanji et al. (2011) reported that the calyx of $H$. sabdariffa L. inhibited $19.4 \%$ of xanthine oxidase enzyme activity, which was lower as compared with this study. The previous and current results are varied in terms of the sample localities and the plant part used for analysis. Furthermore, the flavonoid compounds such as luteolin and apigenin isolated from the flower of Chrysanthemum indicum were shown to exhibit potent xanthine oxidase inhibitory activity (Cos et al., 1998). The major flavonoid, ferulic acid that can be found in Lavandula angustifolia was reported to significantly inhibit more than 50 of xanthine oxidase enzyme activity (Spiridon et al., 2011; Nile et al., 2016).

Hence, the results suggest that all flower extracts are considered as a promising anti-gout agent and the aqueous extracts of Rosa sp., H. sabdariffa L. and Malus sp. with their remarkable xanthine oxidase inhibitory activities should be given priority for further analysis. In addition to the anti-inflammatory and antioxidant activities, the presence of active phytochemicals could act as the natural xanthine oxidase inhibitor and contribute to the anti-gout potential in the flower extracts.

\subsection{Correlation between phytochemicals and xanthine oxidase inhibitory activity}

From the correlation analysis in the study, the total phenolic content was strongly correlated with xanthine oxidase inhibitory activity, which was about $70 \%$. Meanwhile, positive relationships were observed between the total flavonoid content and total anthocyanin content with the xanthine oxidase inhibitory activity, which were $30 \%$ and $40 \%$, respectively. As the result shown in the present study, phytochemical compositions such as phenolics, flavonoids and anthocyanins were positively correlated with the xanthine oxidase inhibitory activity, and the phenolic compounds contributed primarily to the anti-gout activity among the flower extracts. High content of phenolics in Rosa sp. extract resulted in its highest xanthine oxidase inhibitory activity and the strong positive correlation was supported by Kilıçgün and Altıner (2010). A similar observation was also found in Malus sp. due to its high content of phenolics, contributing to its stronger xanthine oxidase inhibition. Other than phenolics, flavonoids and anthocyanins, the compounds including alkaloids, cardiac glycosides, steroids, tannins and terpenoids are responsible for the xanthine oxidase inhibitory activity (Apaya and Chichioco-Hern, 2011) and this could explain the strong anti-gout potency in $H$. sabdariffa $\mathrm{L}$. extract.

\section{Conclusion}

This study clearly demonstrated the potential of Rosa sp., H. sabdariffa L. and Malus sp. as an anti-gout agent due to their stronger xanthine oxidase inhibition abilities recorded with lower $\mathrm{IC}_{50}$ values and rich content of phytochemicals. The preliminary results of this study could be further investigated through the isolation and identification of active constituents among the flower extracts, toxicity test as well as the in vivo experiments for the verification of their abilities in inhibiting the xanthine oxidase enzyme.

\section{Conflict of interest}

The authors do not have any conflicts of interest regarding the content of the present work.

\section{Acknowledgements}

The authors would like to thank the Ministry of Higher education of Malaysia (MoHE) for the research grant under Fundamental Research Grant Scheme (FRGS) Vot: K099 (FRGS/1/2018/WAB01/ UTHM/02/1) as well as Universiti Tun Hussein Onn 
Malaysia (UTHM) for the research grant support (Vot: $\mathrm{H} 277$ ), the use of their laboratory facilities, and their assistance.

\section{References}

Abu Bakar, F.I., Abu Bakar, M.F., Abdullah, N., Endrini, S. and Fatmawati, S. (2020). Optimization of extraction conditions of phytochemical compounds and anti-gout activity of Euphorbia hirta L. (Ara tanah) using response surface methodology and liquid chromatography-mass spectrometry (LC-MS) analysis. Evidence-Based Complementary and Alternative Medicine, 2020, 4501261. https:// doi.org/10.1155/2020/4501261

Abu Bakar, F.I., Abu Bakar, M.F., Rahmat, A., Abdullah N., Sabran, S.F. and Endrini, S. (2018). Anti-gout potential of Malaysian medicinal plants. Frontiers in Pharmacology, 9, e00261. https://doi.org/10.3389/ fphar.2018.00261

Abu Bakar, M.F., Ismail, N.A., Isha, A. and Lee, A.M.L (2016). Phytochemical composition and biological activities of selected wild berries (Rubus moluccanus L., $R$. fraxinifolius Poir., and $R$. alpestris Blume). Evidence-Based Complementary and Alternative Medicine, 2016, 2482930. https:// doi.org/10.1155/2016/2482930

Abu Bakar, M.F., Teh, A.H., Rahmat, A., Hashim, N., Othman, F. and Fakurazi, S. (2006). Antiproliferative properties and antioxidant activity of various types of Strobilanthes crispus tea. International Journal of Cancer Research, 2(2), 152158. http://doi.org/10.3923/ijcr.2006.152.158

Ahmad, N.S., Farman, M., Najmi, M.H., Mian, K.B. and Hasan, A. (2006). Activity of polyphenolic plant extracts as scavengers of free radicals and inhibitors of xanthine oxidase. Journal of Basic and Applied Sciences, 2, 1-6.

Ali Hassan, S.H. and Abu Bakar, M.F. (2013). Antioxidative and anticholinesterase activity of Cyphomandra betacea fruit. The Scientific World Journal, 2013, 278071. https:// doi.org/10.1155/2013/278071

Aoshima, H., Hirata, S. and Ayabe, S. (2007). Antioxidative and anti-hydrogen peroxide activities of various herbal teas. Food Chemistry, 103(2), 617622. https://doi.org/10.1016/j.foodchem.2006.08.032

Apaya, K.L. and Chichioco-hernandez, C.L. (2011). Xanthine oxidase inhibition of selected Philippine medicinal plants. Journal of Medicinal Plants Research, 5(2), 289-292.

Bolling, B.W., Dolnikowski, G., Blumberg, J.B. and Chen, C.Y. (2010). Polyphenol content and antioxidant activity of California almonds depend on cultivar and harvest year. Food Chemistry, 122(3), 819-825.

j.foodchem.2010.03.068

Bustanji, Y., Hudaib, M., Tawaha, K., Mohammad, M.K., Almasri, I., Hamed, S. and Oran, S. (2011). In vitro $x$ anthine oxidase inhibition by selected Jordanian medicinal plants. Jordan Journal of Pharmaceutical Sciences, 4(1), 49-55.

Chen, I.H., Kuo, M.C., Hwang, S.J., Chang, J.M. and Chen, H.C. (2005). Allopurinol-induced severe hypersensitivity with acute renal failure. The Kaohsiung Journal of Medical Sciences, 21(5), 228232. http://doi.org/10.1016/S1607-551X(09)70192-5

Cos, P., Ying, L., Calomme, M., Hu, J.P., Cimanga, K., Van Poel, B., Pieters, L., Vlietinck, A.J. and Berghe, D.V. (1998). Structure-activity relationship and classification of flavonoids as inhibitors of xanthine oxidase and superoxide scavengers. Journal of Natural Products, 61(1), 71-76. https:// doi.org/10.1021/np970237h

Giusti, M.M. and Wrolstad, R.E. (2001). Characterization and measurement of anthocyanins by UV-visible spectroscopy. Current Protocols in Food Analytical Chemistry, 00(1), F1.2.1-F1.2.13. https://doi.org/10.1002/0471142913.faf0102s00

Hudaib, M.M., Tawaha, K.A., Mohammad, M.K., Assaf, A.M., Issa, A.Y., Alali, F.Q., Aburjai, T.A. and Bustanji, Y.K. (2011). Xanthine oxidase inhibitory activity of the methanolic extracts of selected Jordanian medicinal plants. Pharmacognosy Magazine, $\quad 7(28), \quad 320-324 . \quad \mathrm{https}: / /$ doi.org/10.4103/0973-1296.90413

Hussain, N., Ishak, I., Mohd Harith, N. and Leong Pau Kuan, G. (2019). Comparison of bioactive compounds and sensory evaluation on edible flowers tea infusion. Italian Journal of Food Science, 31(2), 264-273.

Jäger, A.K., Eldeen, I.M. and van Staden, J. (2007). COX-1 and -2 activity of rose hip. Phytotherapy Research, 21(12), 1251-1252.

Jin, L., Li, X.B., Tian, D.Q., Fang, X.P., Yu, Y.M., Zhu, H.Q., Ge, Y.Y., Ma, G.Y., Xiao, W.F. and Li, M. (2016). Antioxidant properties and color parameters of herbal teas in China. Industrial Crops and Products, 87, 198-209. https://doi.org/10.1016/ j.indcrop.2016.04.044

Khoo, H.E., Azlan, A., Tang, S.T. and Lim, S.M. (2017). Anthocyanidins and anthocyanins: Colored pigments as food, pharmaceutical ingredients, and the potential health benefits. Food and Nutrition $\begin{array}{llll}\text { Research, } & 61, & 1361779 . & \mathrm{https}: / /\end{array}$ 
doi.org/10.1080/16546628.2017.1361779

Kılıçgün, H. and Altıner, D. (2010). Correlation between antioxidant effect mechanisms and polyphenol content of Rosa canina. Pharmacognosy Magazine, $6(23), \quad 238-241$. https://doi.org/10.4103/09731296.66943

Kong, L.D., Cai, Y., Huang, W.W., Cheng, C.H. and Tan, R.X. (2000). Inhibition of xanthine oxidase by some Chinese medicinal plants used to treat gout. Journal of Ethnopharmacology, 73(1-2), 199-207. https://doi.org/10.1016/s0378-8741(00)00305-6

Kovatcheva-Apostolova, E.G., Georgiev, M.I., Ilieva, M.P., Skibsted, L.H., Rødtjer, A. and Andersen, M.L. (2008). Extracts of plant cell cultures of Lavandula vera and Rosa damascena as sources of phenolic antioxidants for use in foods. European Food Research and Technology, 227(4), 1243-1249.

Kumar, S. and Pandey, A.K. (2013). Chemistry and biological activities of flavonoids: An overview. The Scientific World Journal, 2013, 1-16. http:// dx.doi.org/10.1155/2013/162750

Kumari, P., Ujala and Bhargava, B. (2021). Phytochemicals from edible flowers: Opening a new arena for healthy lifestyle. Journal of Functional Foods, 78, 104375. https://doi.org/10.1016/ j.jff.2021.104375

Lin, C.C., Huang, P.C. and Lin, J.M. (2000). Antioxidant and hepatoprotective effects of Anoectochilus formosanus and Gynostemma pentaphyllum. The American Journal of Chinese Medicine, 28(1), 8796. https://doi.org/10.1142/S0192415X00000118

Malik, N., Khatkar, A. and Dhimana, P. (2019). Computational analysis and synthesis of syringic acid derivatives as xanthine oxidase inhibitors. Medicinal Chemistry, 16(5), 643-653. https:// doi.org/10.2174/1573406415666191004134346

Md Akhir, R.A., Abu Bakar, M.F. and Sanusi, S.B. (2017). Antioxidant and antimicrobial activity of stingless bee bread and propolis extracts. AIP Conference Proceedings 1891, 020090. https:// doi.org/10.1063/1.5005423

Minatel, I.O., Borges, C.V., Ferreira, M.I., Gomez, H.A.G., Chen, C.-Y.O. and Lima, G.P.P. (2017). Phenolic compounds: Functional properties, impact of processing and bioavailability. In SotoHernández, M., Palma-Tenango, M. and GarcíaMateos, R. (Eds). Phenolic compounds-Biological activity, p. 1-25. IntechOpen E-Book.

Mohd Noor, H.S., Abu Bakar, M.F., Abu Bakar, F.I., Ismail, N.A., Sanusi, S.B. and Mohamed, M. (2020). Phytochemical content and antioxidant activity of selected wild ulam/vegetables consumed by indigenous Jakun community in Taman Negara Johor Endau Rompin (TNJER), Malaysia. Food Research, 4(1), 28-33. https://doi.org/10.26656/ fr.2017.4(1).179

Nessa, F., Ismail, Z. and Mohamed, N. (2010). Xanthine oxidase inhibitory activities of extracts and flavonoids of the leaves of Blumea balsamifera. Pharmaceutical Biology, 48(12), 1405-1412. https:// doi.org/10.3109/13880209.2010.487281

Nile, S.H., Ko, E.Y., Kim, D.H. and Keum, Y.S. (2016). Screening of ferulic acid related compounds as inhibitors of xanthine oxidase and cyclooxygenase-2 with anti-inflammatory activity. Revista Brasileira de Farmacognosia, 26(1), 50-55. https:// doi.org/10.1016/j.bjp.2015.08.013

Orhan, D.D., Hartevioğlu, A., Küpeli, E. and Yesilada, E. (2007). In vivo anti-inflammatory and antinociceptive activity of the crude extract and fractions from Rosa canina L. fruits. Journal of Ethnopharmacology, 112(2), 394-400. https:// doi.org/10.1016/j.jep.2007.03.029

Pacher, P.A., Nivorozhkin, A. and Szabó, C. (2006). Therapeutic effects of xanthine oxidase inhibitors: Renaissance half a century after the discovery of allopurinol. Pharmacological Reviews, 58(1), 87114. https://doi.org/10.1124/pr.58.1.6

Spiridon, I., Colceru, S., Anghel, N., Teaca, C.A., Bodirlau, R. and Armatu, A. (2011). Antioxidant capacity and total phenolic contents of oregano (Origanum vulgare), lavender (Lavandula angustifolia) and lemon balm (Melissa officinalis) from Romania. Natural Product Research, 25(17), 1657-1661.

https:// doi.org/10.1080/14786419.2010.521502

Tungmunnithum, D., Thongboonyou, A., Pholboon, A. and Yangsabai, A. (2018). Flavonoids and other phenolic compounds from medicinal plants for pharmaceutical and medical aspects: An overview. Medicines, 5(3), 1-16. https://doi.org/10.3390/ medicines5030093

Unno, T., Sugimoto, A. and Kakuda, T. (2004). Xanthine oxidase inhibitors from the leaves of Lagerstroemia speciosa (L.) Pers. Journal of Ethnopharmacology, 93(2-3), 391-395. https://doi.org/10.1016/ j.jep.2004.04.012

Vankar, P.S. and Srivastava, J. (2010). Evaluation of anthocyanin content in red and blue flowers. International Journal of Food Engineering, 6(4), 113.

Wahyuningsih, S., Sukandar, E.Y. and Sukrasno. (2016). In vitro xanthine oxidase inhibitor activity of ethanol extract and fraction Roselle Calyx (Hibiscus 
sabdariffa L.). International Journal of Pharmacutical and Clinical Research, 8(6), 619622.

Yang, H. and Shin, Y. (2017). Antioxidant compounds and activities of edible roses (Rosa hybrida spp.) from different cultivars grown in Korea. Applied Biological Chemistry, 60, 129-136. https:// doi.org/10.1007/s13765-017-0261-4

Zheng, J., Yu, X., Maninder, M. and Xu, B. (2018). Total phenolics and antioxidants profiles of commonly consumed edible flowers in China. International Journal of Food Properties, 21(1), 1524-1540.

https://

doi.org/10.1080/10942912.2018.1494195 